\title{
Digestibility of energy and nutrients in pigs previously fed a high-fibre diet $^{*}$
}

\author{
St. Raj ${ }^{1}$, G. Skiba, D. Weremko and H. Fandrejewski \\ The Kielanowski Institute of Animal Physiology and Nutrition, \\ Polish Academy of Sciences \\ 05-110 Jablonna, Poland
}

(Received 25 May 2006; revised version 8 September 2006; accepted 6 November 2006)

\begin{abstract}
The aim of this experiment was to investigate total tract apparent digestibility of energy and nutrients in pigs previously fed a diet supplemented with $20 \%$ grass meal (high-fibre diet). Thirty-six pigs of 25 $\mathrm{kg}$ BW were randomly allotted to 4 treatment groups. The pigs were fed ad libitum a basal diet (B) or a high-fibre diet (HF) during the entire experiment (control group $\mathrm{C}$ and group HF105, respectively), or a high-fibre diet up to 50 or $80 \mathrm{~kg} \mathrm{BW}$ (groups HF50 and HF80, respectively) followed by diet B up to $105 \mathrm{~kg} \mathrm{BW}$. Diet B contained (in $\mathrm{gDM}^{-1}$ ): crude protein, 212; crude fibre, 43; total lysine, 11.1 and gross energy, 18.0 MJ. Diet HF was formulated by mixing diet B with $20 \%$ of grass meal and contained (in $\mathrm{gDM}^{-1}$ ): crude protein, 191; crude fibre, 85; total lysine, 9.1 and gross energy, $18.3 \mathrm{MJ}$.

The apparent digestibility of energy and nutrients was measured within a short time after exchanging diet HF for diet B (at approximately 55 and $85 \mathrm{~kg} \mathrm{BW}$ ) using an indirect method (with chromic oxide as an indicator). The apparent digestibility of energy and nutrients of diet HF was on average approximately $10 \%$ lower $(\mathrm{P}<0.01)$ than in diet $\mathrm{B}$. Consequently, the energy value of diet HF was 1.67 MJ DE lower than in diet B. The digestibilities of energy and nutrients of diet $\mathrm{B}$ fed after the diet with a high fibre content (HF50 and HF80 groups) were not affected by the preceding diet, with the exception of the digestibility of crude fibre, NDF and ADF fractions, which were digested approximately $2.0 \%$ better, and ether extract, which was digested $3.2 \%$ worse (non significant difference). When the digestibilities of energy and nutrients in pigs weighing 55 and 85 $\mathrm{kg}$ were compared, however, it was found that heavier pigs digested $(\mathrm{P}<0.05)$ energy and protein (average by 1.0 and 1.9\%) and crude fibre, NDF and ADF (by 8.2, 2.7 and 4.5\%, respectively) more efficiently than pigs at $55 \mathrm{~kg} \mathrm{BW}$. Consequently, the energy value of diets fed to pigs at $85 \mathrm{~kg} \mathrm{BW}$ was greater by $145 \mathrm{kJDE}^{-1}(\mathrm{P}>0.05)$ than at $55 \mathrm{~kg} \mathrm{BW}$.
\end{abstract}

KEY WORDS: pig, fibre, apparent digestibility, energy, nutrients

\footnotetext{
"Funded by The European Commission (V Framework Programme) within the international project "Sustainability in the production of pork with improved nutritional and eating quality using strategic feeding in out-door production". Contract No. QLK5-CT-2000-00162

${ }^{1}$ Corresponding author: e-mail: s.raj@ifzz.pan.pl
} 


\section{INTRODUCTION}

High-fibre components are included very often in diets for growing pigs in out-door production. Such feeds influence the mass, composition and morphology of the gastrointestinal tract (Jin et al., 1994) as well as digesta content (Whittemore et al., 2003). The higher content of fibrous material in the diet reduces transit time, allowing less time for enzymatic digestion and absorption in the small intestine and increases the proportion of nutrients being transferred to the large intestine (Just et al., 1981). Furthermore, it decreases the apparent digestibility of energy and nutrients (Fernandez and Jørgensen, 1986; Jin et al., 1994; Jørgensen et al., 1996; Andersson, 1997; Wenk, 2001). An increased dietary fibre content throughout the fattening period restricts the growth of pigs and, consequently, deteriorates their performance.

This is why these systems are being increasingly modified and high-fibre components are offered as an extra supplement or commercial/standard diets are diluted with these components and fed to pigs in the first growth period, after which feeding with commercial/standard diets resumes. After such a change in diets pigs should grow faster due to the effect of compensatory growth, which usually occurs shortly after the diet change (Skiba et al., 2001; Lawrence et al., 2002). Compensatory growth results from a greater amount of protein being deposited in the body as well as from better efficiency of protein and energy utilization.

However, there is no information on the apparent digestibility of energy and nutrients in growing pigs periodically fed high-fibre diets. Thus, the objective of the present experiment was to test the hypothesis that the apparent digestibility of energy and nutrients of pigs previously fed a fibre-rich diet up to 50 or $80 \mathrm{~kg} \mathrm{BW}$ followed by a concentrate diet up to $105 \mathrm{~kg}$ BW would be higher compared with control animals continuously fed a commercial diet.

\section{MATERIAL AND METHODS}

Thirty-six crossbred pigs ( $₫$ Duroc $\times q$ Large White) at $25 \mathrm{~kg}$ BW were randomly allotted to 4 treatment groups and up to $105 \mathrm{~kg} \mathrm{BW}$ kept individually and fed according to the scheme presented in Table 1. The pigs were fed a basal diet (B) or high-fibre diet (HF) during the entire experiment (control group $\mathrm{C}$ and group HF105, respectively). The other animals were fed a HF diet up to 50 or $80 \mathrm{~kg} \mathrm{BW}$ (groups HF50 and HF80, respectively) and afterwards the B diet up to $105 \mathrm{~kg} \mathrm{BW}$. The pigs were fed ad libitum during the whole experimental period. Feed intake was measured weekly during both the restriction and realimentation periods and calculated as the difference between the amount of feed given and remaining. 
Table 1. Experimental design

\begin{tabular}{lccc}
\hline & \multicolumn{3}{c}{ Feed applied during particular growth period } \\
\cline { 2 - 4 } Group & $\mathrm{BW}, \mathrm{kg}$ & $80-105$ \\
\cline { 2 - 4 } & $25-50$ & $50-80$ & $\mathrm{~B}$ \\
$\mathrm{C}$ & $\mathrm{B}$ & $\mathrm{B}$ & $\mathrm{B}$ \\
HF50 & $\mathrm{HF}$ & $\mathrm{B}$ & $\mathrm{B}$ \\
HF80 & $\mathrm{HF}$ & $\mathrm{HF}$ & $\mathrm{HF}$ \\
HF105 & $\mathrm{HF}$ & $\mathrm{HF}$ & $\mathrm{HF}-\mathrm{g}$ \\
\hline
\end{tabular}

C - control group, the pigs fed the basal diet (B) throughout of the study; HF50 and HF80 - groups of pigs fed high fibre diet (HF) up to 50 or $80 \mathrm{~kg} \mathrm{BW}$, respectively, and afterwards the basal diet; HF105 - group of pigs fed the high fibre diet throughout of the study

Two diets were formulated in pelleted form (4 $\mathrm{mm}$ diameter). Diet B was composed of, $\mathrm{g} \mathrm{kg}^{-1}:$ barley 309 , wheat 297 , triticale 90 , maize 50 , soyabean oilmeal 180 , rapeseed oilmeal 50, crystalline amino acids and vitamin-mineral premix 24 , and contained in dry matter $\left(\mathrm{g} \cdot \mathrm{DM}^{-1}\right)$ : crude protein 212 , crude fibre $(\mathrm{CF})$ 43, total lysine 11.1, total methionine 3.4 and gross energy (GE) 18.0 $\mathrm{MJ}^{-1} \mathrm{DM}^{-1}$. The HF diet was formulated by mixing diet B with $20 \%$ of grass meal and contained (in $\mathrm{g}^{-\mathrm{DM}^{-1}}$ ): CP 191, CF 85, total lysine 9.1, total methionine 2.9 and GE $18.3 \mathrm{MJ}^{\mathrm{DM}}{ }^{-1}$.

The apparent digestibility of energy and nutrients was measured when pigs reached 55 and $85 \mathrm{~kg} \mathrm{BW}$. Chromic oxide $(0.2 \%)$ was included in the diets as a digestibility marker prior to incorporation into the diets, which were finely ground through a $2 \mathrm{~mm}$ mesh screen. Each experimental period consisted of a 5 -d adaptation period followed by a $3-d$ faeces collection. Faeces were collected at 08.00 and $15.00 \mathrm{~h}$ and were immediately frozen at $-20^{\circ} \mathrm{C}$. After each experimental period, the faeces were pooled within pig, ground through a 1-mm mesh screen, mixed, and a representative subsample was used for chemical analysis.

Samples of diets were ground through a $0.5 \mathrm{~mm}$ mesh screen before analyses. Diets and faeces were analysed for dry matter (DM), crude protein (CP), ether extract (EE), ash and crude fibre (CF) according to AOAC (1995). GE was measured using an adiabatic bomb calorimeter (IKA C5000, Staufen, Germany). The neutral detergent fibre (NDF) and acid detergent fibre (ADF) contents were determined using a Fibertec System M by the method described by Van Soest (1973). The chromic oxide contents in the diets and faeces were measured according to Fenton and Fenton (1979).

Statistical analysis of results was obtained by ANOVA analysis of variance using Statgraphics centurion, version XV. 


\section{RESULTS}

The pigs of groups HF50, HF80 and HF105 were treated the same as when grown from 25 to $50 \mathrm{~kg} \mathrm{BW}$, similarly, the pigs of groups HF80 and HF105, as when grown from $25-80 \mathrm{~kg} \mathrm{BW}$. Average daily feed intake did not differ (1.90 and $1.94 \mathrm{~kg}$ ) between groups of the pigs fed B or HF diets. Prolonged feeding of diet HF to pigs up to $80 \mathrm{~kg} \mathrm{BW}$ increased its intake by $5.1 \%$ (2.54 vs $2.67 \mathrm{~kg}$ ) during growth from 50 to $80 \mathrm{~kg} \mathrm{BW}$. In fact, pigs fed diet HF began to eat more feed from the $6^{\text {th }}$ week of the restriction period. The growth rate of the pigs fed diet $\mathrm{HF}$, as compared with controls, was slower $(\mathrm{P}<0.05)$ by $12.3 \%$ ( $789 \mathrm{vs} 900 \mathrm{~g} /$ day, respectively) in the first period from 25 to $50 \mathrm{~kg} \mathrm{BW}$ and similar (921 and 934 $\mathrm{g}$ /day) during the next period of growth from 50 to $80 \mathrm{~kg} \mathrm{BW}$.

Group HF50 pigs consumed more (by 2.72 vs $2.54 \mathrm{~kg}$; $\mathrm{P}<0.05$ ) feed daily and grew faster ( 993 vs $930 \mathrm{~g} \cdot$ day $^{-1} ; \mathrm{P}<0.05$ ) than pigs of group $\mathrm{C}$, but only up to $80 \mathrm{~kg}$ $\mathrm{BW}$. The feed intake and growth rate of the HF80 group pigs were similar to the control group $\left(3.1 \mathrm{~kg}^{-1}\right.$ day and $988 \pm 48 \mathrm{~g} \cdot \mathrm{day}^{-1}$, respectively).

In the overall growth period, pigs of groups HF50 and HF105 consumed daily more $(\mathrm{P}<0.05)$ feed as compared with the $\mathrm{C}$ and HF80 pigs (average 2.67 vs 2.49 $\mathrm{kg}$, respectively). Moreover, the average daily gain of the HF50 and $\mathrm{C}$ animals was similar and higher $(\mathrm{P}<0.05)$ compared with pigs of groups HF80 and HF105 (average 940 vs $870 \mathrm{~g}$, respectively).

The high-fibre diet had more crude fibre in $\mathrm{gDM}^{-1}$ ( $85 \mathrm{vs} \mathrm{43)}$ and both NDF (254 vs 151) and ADF (113 vs 66) fibre fractions compared with the basal diet. With increasing of CF, NDF and ADF in the diet there was a significant $(\mathrm{P}<0.01)$ reduction of CP (by $21 \mathrm{~g}$ ), but no change in GE content (average 18.3 MJ) in the diets.

The increased fibre content from 43 to 88 in $\mathrm{DDM}^{-1}$ of mixture negatively affected GE and CP digestibility (average for treatment, by 11.8 and $10.2 \%$, respectively; $\mathrm{P}<0.01$ ). Also the digestibility of $\mathrm{EE}, \mathrm{CF}, \mathrm{NDF}$ and ADF was significantly by lower $(\mathrm{P}<0.01)$ in the HF than in the B diet (average for treatments, by 15.2, 7.4, 6.8 and $9.7 \%$, respectively) (Table 2). Consequently, the energy value of the highfibre diet was lower by $1.67 \mathrm{MJ} \cdot \mathrm{DE}^{-1}$ than of the basal diet.

The total tract digestibility of energy and nutrients in diets B and HF was higher $(\mathrm{P}<0.05)$ in pigs weighing $85 \mathrm{~kg}$ compared with pigs weighing $55 \mathrm{~kg}$. The differences between the two groups of pigs were smaller for digestibility of energy and protein (average by 1.0 and $1.9 \%$, respectively) and larger for digestibility of CF, NDF and ADF (by 8.2, 2.7 and 4.5\%, respectively). The higher digestibility of energy and nutrients, especially $\mathrm{CF}$, did not significantly influence the content of digestible energy in the diets (difference was about 145 $\left.\mathrm{kJ} \cdot \mathrm{DE}^{-1} ; \mathrm{P}>0.05\right)$. 
The digestibilities of energy and nutrients of diet $\mathrm{B}$ fed after the diets with a high fibre content (HF50 and HF80 groups) were not affected by the preceding diet, with the exception of the digestibility of CF, NDF and ADF fractions, which were digested better by an average of $2.0 \%$, and of the EE, which was digested worse by $3.2 \%(\mathrm{P}>0.05)$.

Table 2. Digestibility (\%) of energy and nutrients in pigs fed basal or high fibre diet throughout of the study and in pigs fed high fibre diet up to 50 or $80 \mathrm{~kg} \mathrm{BW}$

\begin{tabular}{|c|c|c|c|c|c|c|c|c|c|c|}
\hline \multirow{4}{*}{ Item } & \multicolumn{6}{|c|}{ Group } & \multirow{4}{*}{ SEM } & \multicolumn{3}{|c|}{ Difference } \\
\hline & $\mathrm{C}$ & $\mathrm{C}$ & HF105 & HF105 & HF50 & HF80 & & \multirow{3}{*}{$\begin{array}{c}\text { C vs } \\
\text { HF105 }\end{array}$} & \multirow{3}{*}{$\begin{array}{c}\mathrm{C} \text { vs HF } \\
50 \text { and } 80\end{array}$} & \multirow{3}{*}{$\begin{array}{l}\mathrm{BW}, \mathrm{kg} \\
55 \mathrm{vs} 85\end{array}$} \\
\hline & \multicolumn{6}{|c|}{$\mathrm{BW}, \mathrm{kg}$} & & & & \\
\hline & 55 & 85 & 55 & 85 & 55 & 85 & & & & \\
\hline Gross energy & 84.4 & 85.4 & 72.6 & 73.6 & 84.3 & 85.3 & 0.26 & $* *$ & NS & $*$ \\
\hline Crude protein & 79.7 & 81.8 & 70.0 & 71.1 & 79.3 & 81.8 & 0.33 & $* *$ & NS & $*$ \\
\hline Ether extract & 65.4 & 66.1 & 52.1 & 48.9 & 63.6 & 61.3 & 0.44 & $* *$ & NS & $*$ \\
\hline Ash & 44.3 & 44.8 & 37.6 & 38.4 & 44.8 & 45.1 & 0.48 & $* *$ & NS & NS \\
\hline Crude fibre & 31.7 & 39.2 & 23.0 & 33.1 & 34.5 & 41.5 & 0.93 & $* *$ & NS & $*$ \\
\hline NDF & 48.7 & 50.7 & 40.7 & 45.0 & 51.1 & 52.9 & 1.23 & NS & NS & $*$ \\
\hline $\mathrm{ADF}$ & 40.8 & 46.7 & 33.0 & 35.1 & 43.5 & 48.9 & 1.02 & $* *$ & NS & $*$ \\
\hline
\end{tabular}

$\mathrm{C}$ - control group, the pigs fed the basal diet throughout of the study; HF105 - group of pigs fed the high fibre diet throughout of the study; HF50 and HF80 - groups of pigs fed high fibre diet up to 50 or $80 \mathrm{~kg} \mathrm{BW}$, respectively, and afterwards the basal diet

${ }^{*} \mathrm{P}<0.05 ;{ }^{* *} \mathrm{P}<0.01$

\section{DISCUSSION}

The chemical composition of the diets reflects differences in both the proportion of ingredients and their composition. Inclusion of grass meal into the basal diet increased the CF content and both NDF and ADF fractions and decreased total digestibility of energy and nutrients in the diets. As a consequence, the high-fibre diet was unbalanced with regard to energy and ileal apparent digestible amino acids; the amount of these nutrients was lower than the requirement of growing pigs (NRC, 1998).

Increasing the intake of the high-fibre diet during the second period of growth allowed the pigs to consume greater amounts of energy and amino acids, which caused their growth rate during the period from 50 to $80 \mathrm{~kg} \mathrm{BW}$ to be only slightly lower compared with pigs fed the basal diet during the whole experimental period. In effect, this unexpected response of pigs caused the severity of the restriction to lessen as its duration increased.

In our experiment the pigs given the high-fibre diet had a lower digestibility of energy, $\mathrm{CP}$ and other nutrients than those given the basal diet, which is in 
agreement with earlier reports (e.g., Fernandez and Jørgensen, 1986; Whittemore et al., 2003). The high (20\%) supplement of grass meal to diet B lowered energy and protein digestibility to a greater extent than a $20 \%$ supplement of lucerne meal or clover silage in the study by Andersson (1997). The disagreement between our results and the cited ones is probably due to the kind of fibre component supplemented to the diet as well as to the duration of feeding the pigs with highfibre diets.

The present data suggest that the decrease in total tract digestibility of GE and $\mathrm{CP}$ might be of greater magnitude than that of fibrous components (CF, NDF and ADF) when forage meals are included in a cereal-based diet. A similar observation was made by Stanogias and Pearce (1985) and Andersson (1997). This could be due to a faster passage rate of feed through the alimentary tract and to increased excretion of dietary components bound or physically entrapped in the bulk of the bolus of the fibrous digesta (Eastwood and Kay, 1979; Whittemore et al., 2003).

In our experiment, the apparent total tract digestibility of the EE decreased when the basal diet was supplemented by grass meal. The negative effect can be explained by endogenous losses of EE associated with the microbial mass excreted in the faeces (Bayley and Lewis, 1993) and suggests a net production of fat in the large intestine (Shi and Noblet, 1993) when forage meals are included in cereal-based diets for pigs.

Jørgensen et al. (1996) and Andersson (1997) found that fibrous material in the diet increased digesta in alimentary tract and also increased the proportion of energy and nutrients being transferred to the large intestine, probably due to reduced transit time allowing less time for enzymatic digestion and absorption in the small intestine. It is logical that the time digesta remains in the digestive tract is related to the extent of the digestibility of its components. These authors reported that dietary fibre is not digested during the endogenous/enzymatic processes occurring in the small intestine, but that it is digested very efficiently by the microbial flora of the large intestine. Therefore, an abundance of fibre in the large intestine, caused by feeding pigs a diet rich in this component, considerably increases the activity of microbial flora in this segment of the gastrointestinal tract (Derick et al., 1989; Jørgensen et al., 1996; Whittemore et al., 2003). The study presented by Fernandez and Jorgensen (1986) showed that increasing the content of CF in the diets is related to increasing the content of less digestible carbohydrate (hemicellulose) and a concurrent decrease in the content of easily digestible substances. These authors showed that for each $1 \%$ increase in the CF content, the content of starch and sugars in the $\mathrm{N}$-free extractives fraction is decreased by $2.5 \%$. This resulted in reduced ileal digestibility, enhanced fermentation in the hindgut, and overall reduction of the digestibility of GE and the content of digestible energy in the diet. 
Our results proved that the values of apparent digestibility of energy and CP were less influenced by the BW of the pigs than the CF content in the diet. These results are in agreement with those of Shi and Noblet (1993) and Goff et al. (2002). Therefore, the differences in the digestibility of energy and other nutrients between growing and finishing pigs are usually ignored (e.g., Shi and Noblet, 1993).

During the period following feeding the high-fibre diet, the digestibility of energy, protein and other nutrients of diet B was not affected by the diet fed previously. A tendency towards better digestion of CF, NDF and ADF fractions by pigs fed earlier on the diet with a greater fibre content was probably caused by higher activity of microflora in the hindgut. Our earlier study (Raj et al., 2005) showed that the amount of digesta in the pigs previously (up to 50 or up to $80 \mathrm{~kg} \mathrm{BW}$ ) fed the diet containing grass meal was greater than in the pigs fed the basal diet during the whole of the experiment. This was a result of the previous influence of dietary fibre on mass/capacity and microbial activity of the large intestine.

\section{CONCLUSIONS}

Contrary to expectations, previous feeding of a high-fibre diet (regardless of duration) to pigs did not improve the apparent digestibility of energy and nutrients in the basal diet. Moreover, our study proved that values of apparent digestibility of energy and crude protein were less influenced by the BW of the pigs than by the $\mathrm{CF}$ content in the diet.

\section{REFERENCES}

Andersson Ch., 1997. Forages for growing pigs. Partition of digestion and nutritive value. PhD. Thesis, Swedish University of Agricultural Science, Uppsala (Sweden)

AOAC, 1995. Official Methods of Analysis, Association of Official Analytical Chemists. $15^{\text {th }}$ Edition. Arlington, VA

Bayley H.S., Lewis D., 1965. The use of fats in pig feeding. 1. Pig faecal fat not of immediate dietary origin. J. Agr. Sci. 64, 367-372

Derick N.A., Vervaeke I.J., Demeyer D.I., Decuypere J.A., 1989. Approach to the energetic importance of fibre digestion in pigs. I. Importance of fermentation in the overall energy supply. Anim. Feed Sci. Tech. 23, 141-167

Eastwood M.A., Kay R.M., 1979. An hypothesis for the action pf dietary fiber along the gastrointestinal tract. Amer. J. Clin. Nutr. 32, 364-367

Fenton T.W., Fenton M., 1979. An improved procedure for the determination of chromic oxide in feed and feces. Can.J. Anim. Sci. 59, 631-634

Fernandez J.A., Jørgensen J.N., 1986. Digestibility and absorption of nutrients as affected by fibre content in the diet of the pigs. Quantitative aspects. Livest. Prod. Sci. 15, 53-71 
Goff G., von Milgen J., Noblet J., 2002. Influence of dietary fiber on digestive utilisation and rate of passage in growing pigs, finnishing pigs and adult sows. Anim. Sci. 74, 503-515

Jin L., Reynolds L.P., Redmer D.A., Caton J.S., Crenshaw J. D., 1994. Effects of dietary fiber on intestinal growth, cell proliferation, and morphology in growing pigs. J. Anim. Sci. 72, 22702278

Jørgensen H., Zhao X.Q., Eggum B.O., 1996. The influence of dietary fibre and environmental temperature on the development of the gastrointestinal tract, digestibility, degree of fermentation in the hind-gut and energy metabolism in pigs. Brit. J. Nutr. 75, 365-378

Just A., Jørgensen H., Fernandez J.A., 1981. The digestive capacity of the caecum-colon and the value of the nitrogen absorbed from the hind gut for protein synthesis in pigs. Brit. J. Nutr. 46, 209-219

Lawrence T.L.J., Fowler V.R., 2002. Compensatory growth. In: Growth of Farm Animals. CABI, pp. 229-254

NRC, 1998. Nutrient Requirement of Swine. $10^{\text {th }}$ Edition. National Academy Press. Washington, DC

Raj St., Skiba G., Weremko D., Fandrejewski H., 2005. Growth of the gastrointestinal tract of pigs during realimentation following a high-fibre diet. J. Anim. Feed Sci. 14, 675-684

Shi X.S., Noblet J., 1993. Contribution of the hindgut to digestion of diets in growing pigs and adult sows: effect of diet composition. Livest. Prod. Sci. 34, 237-252

Skiba G., Fandrejewski H., Raj St., Weremko D., 2001. The performance and body composition of growing pigs during protein or energy deficiency and subsequent realimentation. J. Anim. Feed Sci. 10, 633-647

Stanogias G., Pearce G.R., 1985. The digestion of fibre by pigs. I. The effects of amount and type of fibre on digestibility, nitrogen balance and rate of passage. Brit. J. Nutr. 53, 513-530

Van Soest P.J., 1973. Collaborative study of acid detergent fiber and lignin. J. Assn. Off. Chem. 56, 513-530

Wenk C., 2001. The role of dietary fibre in the digestive physiology of the pig. Anim. Feed Sci. Tech. 90, 21-33

Whittemore C.T., Emmans G.C., Kyriazakis I., 2003. The problem of predicting food intake during the period of adaptation to new food: a model. Brit. J. Nutr. 89, 383-398 